\title{
DISTURBANCE OF THE FUNCTIONALITY IN IMMUNOCOMPETENT ORGANS OF CHICKENS DUE TO ACCUMULATION OF CADMIUM
}

\author{
Svetlana Vasiljeva, Nataliya Basova, Galina Smirnova \\ University of Latvia, Latvia \\ svetlana.vasiljeva@lu.lv
}

\begin{abstract}
The high toxicity, bioaccumulative and increased distribution of cadmium (Cd) in the environment, makes it the most dangerous to any biological system, including immune system in human and animals. The effect of dietary intake of Cd (8.25 mg per kg) on accumulation and distribution of this heavy metal in various tissues, and functional changes in organs of immunity (thymus, bursa of Fabricius, spleen) in 35-day-old broiler cockerels were investigated, using biochemical and immunological methods. Significant increases in the $\mathrm{Cd}$ concentration both in central immunocompetent organs (thymus, bursa of Fabricius) and peripheral (spleen) were established. Excessive tissue level of Cd induced the prooxidative effect of this heavy metal in the organs. It was manifested in an increase of cell membrane lipid peroxidation (the enhanced malondialdehyde (MDA) concentration) in immune system organs. The oxidative stress resulted in immunocompetent cell damage. The fall of vital dye absorptive ability of immunocyte indicated the increase in the injured cell number. This harmful effect is in accordance with T- and B (C3) - population prominent depletion, organ relative mass reduction, and growth retardation in chicks, and was established as a result of dietary Cd loading for 5 weeks of the experiment.
\end{abstract}

Key words: cadmium, harmful action, immune organs, chickens.

\section{Introduction}

It is generally accepted that environmental sources of cadmium (Cd) are increasing during the last century. As it is known, Cd concentrations in soil and crops increase by about $0.2 \%$ per year (Järup et al., 1998; Järup \& Åkesson, 2009; Moulis \& Thèvenod, 2010; Kah, Levy, \& Brown, 2012). Due to this persistence and bioaccumulativity Cd can easily enter in the food chain and play a role of a risk factor for some diseases. Excessive accumulation of Cd in humans and animals is associated with various unfavourable effects in organism. Cd is accumulated mainly in the kidney and liver, and impairs the physiological functions of these organs (Ferraro et al., 2010; Galazyn-Sidorczuk et al., 2012; Wallin et al., 2014). Cd is known to cause also immunological disturbances in human and animals (Bokori \& Fekete, 1995; El-Boshy et al., 2015; Wang et al., 2017; Zhang et al., 2017). A toxic effect of Cd occurs mainly in a production of reactive oxygen species, which can cause damage to cellular membrane lipids (Brzóska \& Rogalska, 2013; Nair et al., 2013). In scientific studies (Erdogan et al., 2005), and our previous investigations the harmful accumulation of lipid product, malondialdehyde (MDA), in liver and kidney tissues of chickens exposed by $\mathrm{Cd}$ was established (Berzina et al., 2002; Berzina et al., 2007). Therefore, it is interesting to consider a problem, how the Cd retention in immunocompetent organs is reflected on the immune system responses in birds.

Abird is considered to be a good experimental model because of its accelerated metabolism in comparison of mammals. The main important feature of the birds immune system is the presence of two central lymphoid organs - thymus and bursa of Fabricius - which, excepting bone marrow, are believed to be the primary sites of lymphocyte development. The important peripheral immunocompetent organ is spleen. Its principal functions are phagocytosis and breakdown of effete erythrocytes by macrophages, lymphopoesis and antibody production (Davison, 2013; Olah, Nagu, \& Vervelde, 2013). Lymphoid organs form both adaptive and innate immune responses, and provide to organisms their resistance mechanisms and homeostasis maintenance. There were two primary aims of the present study: (1) to determine a content of Cd in organs of immunity and target organs of this metal in chickens after Cd exposure; (2) to evaluate the effect of Cd accumulation in tissues on the functional changes in immune system organs.

\section{Materials and Methods}

All experimental procedures were approved by the Animal Ethics Committee of the Food and Veterinary Service (Riga, Latvia, authorisation reference number 13, December 22, 2008).

One day-old cockerels (Hybro $G$ broiler breeder) from Kekava Poultry farm were used for the laboratory investigations. Chickens were housed in a cage and divided into two groups of 20 heads each. The birds of the $1^{\text {st }}$ group (control) fed a standard wheat-barley based diet balanced in all nutrients and contained $0.75 \mathrm{mg} \mathrm{Cd}$ per kg. Cd (7.5 mg per kg as $\mathrm{CdCl}_{2}$ solution) supplemented the diet of the $2^{\text {nd }}$ group from the first day. Summary Cd loading in this group of chickens was $8.25 \mathrm{mg}$ per $\mathrm{kg}$ of diet. This dietary dose of $\mathrm{Cd}$ can be considered a subtoxic one for broilers. The toxic Cd level for broiler chickens, as described by National Research Council (1994) is recognized $25 \mathrm{mg} \mathrm{Cd}$ per $\mathrm{kg}$ of diet. The duration of the experiment was 35 days. Seven days before the end of the experiment immunization of chickens by intraperitoneal injection of sheep erythrocytes $(10 \%$ 
suspension) was performed to assess the effect of Cd on immune response. At the end of the experiment, the 35-day-old chickens were weighted and decapitated. The inner organs, including organs of immune system, liver, kidneys, spleen, thymus and bursa of Fabricius were dissected, weighted and tissue samples were used for analyses. Cadmium determination of the tissue samples was performed after dry ashing in atomic absorption spectrophotometer Perkin-Elmer (model AAnalyst 700), according to the procedures of the AOAC (1999). Lipid peroxidation in tissues was determined by thiobarbituric acid reaction as MDA by method of Ohkawa (Ohkawa, Ohishi, \& Yagi, 1979) in modification of Surai (Surai, Noble, \& Speake, 1996). The parameters of immune functioning immunocompetent organs were investigated using partly the complex of methods presented by Vasiljeva (Васильева) (Васильева, Берзиня, \& Ремез, 2001). The immunocyte response in lymphoid organs to Tand B-cell markers (sheep erythrocytes for T-cells and zymozan-C3 complexes for B(C3)-cells) was estimated by the rosette formation reaction. To appreciate $\mathrm{Cd}$ action on the functioning of immunocompetent cells of chicken bursa of Fabricius, a vital dye (Evans blue) index of bursocyte was determined using a method devised by authors. This index indicates the relative amount of uninjured cells and allows evaluating the cytotoxic effect of Cd.

All statistics were performed using the SPSS. Results are expressed as means \pm SE in individual groups and were tested by using the independent Student's t-test. Statistical significance was set at $\mathrm{P}<0.05$ for all statistical analyses.

\section{Results and Discussion}

A high bioaccumulative capacity and long biological half-life of $\mathrm{Cd}$ are well established. Especially large amounts of it accumulate in human and animal kidneys and liver (Brzóska, Borowska, \& Tomczyk, 2016). The data of Table 1 show a dramatic accumulation of $\mathrm{Cd}$ in inner organs of chickens after Cd dietary loading.

Thereafter, the exceptionally large amounts of Cd were detected in chicken kidneys and liver. The intensive increase of Cd content was also observed in investigated organs of immune system of Cdtreated chickens. The highest retention of $\mathrm{Cd}, 13.2$ times more than in control $(\mathrm{P}<0.001)$, was found in bursa of Fabricius, unique only to birds central immunocompetent organ that plays the main role in humoral antibody production. The other central organ of immunity, thymus, that is responsible for the lymphocyte system, important in cellular immunity, accumulated $\mathrm{Cd}$ in a lesser degree than bursa. This index here was only 3.4 times higher in comparison with the control group $(\mathrm{P}<0.001)$. A tissue peripheral lymphoid organ, spleen, that provides processes of phagocytosis, lymphopoiesis and antibody production, also rather actively includes $\mathrm{Cd}, 8.2$ times higher than control $(\mathrm{P}<0.001)$. An increased tissue concentration of $\mathrm{Cd}$ in chicks results in different adverse effects, including tissue damage. Histopathological changes in 11 inner organs were established by Bokori et al. (1995) in studies on broiler chickens treated by different doses of Cd (2.5 - 600 ppm per day). The administration of even small amounts of Cd caused tissue damage, including tubulnephrosis in kidney

\section{Cadmium content in several chicken tissues depending on cadmium exposure}

\begin{tabular}{|l|c|c|c|c|c|}
\hline \multirow{3}{*}{ Group } & \multicolumn{5}{|c|}{ Cadmium, $\mu \mathrm{g} \mathrm{g}^{-1}$ wet wt } \\
\cline { 2 - 6 } & Liver & Kidney & Spleen & Thymus & Bursa of Fabricius \\
\hline Control & $0.42 \pm 0.02$ & $0.50 \pm 0.03$ & $0.63 \pm 0.06$ & $0.40 \pm 0.07$ & $0.60 \pm 0.16$ \\
\hline+ Cd & $34.40 \pm 2.10^{*}$ & $52.40 \pm 0.92^{*}$ & $5.15 \pm 0.92^{*}$ & $1.35 \pm 0.21^{*}$ & $7.90 \pm 1.27^{*}$ \\
\hline
\end{tabular}

* Statistically different from the control group $(\mathrm{P}<0.001)$.

Table 2

Concentration of malondialdehyde in tissue of liver, kidney and immunocompetent organs of chickens exposed to cadmium

\begin{tabular}{|l|c|c|c|c|c|}
\hline \multirow{3}{*}{ Group } & \multicolumn{5}{|c|}{ Malondialdehyde, $\mu \mathrm{M} \mathrm{g}^{-1}$ wet wt } \\
\cline { 2 - 6 } & Liver & Kidney & Spleen & Thymus & Bursa of Fabricius \\
\hline Control & $19.3 \pm 0.1$ & $18.9 \pm 0.1$ & $25.2 \pm 2.2$ & $6.8 \pm 0.4$ & $5.6 \pm 1.3$ \\
\hline+ Cd & $25.0 \pm 0.7^{*}$ & $33.0 \pm 0.1^{*}$ & $27.5 \pm 2.1$ & $8.8 \pm 0.7^{*}$ & $8.8 \pm 0.4$ \\
\hline
\end{tabular}

\footnotetext{
${ }^{*}$ Statistically different from the control group $(\mathrm{P}<0.05)$
} 


\section{Changes in immunological indices induced by $\mathrm{Cd}$ in chicken organs of immunity}

\begin{tabular}{|l|c|c|}
\hline \multicolumn{1}{|c|}{ Group } & Control & + Cd \\
\hline Thymus & & $26.0 \pm 4.0^{*}$ \\
T-immunocytes, \% & $55.0 \pm 1.3$ & $29.4 \pm 5.2^{*}$ \\
Thymocyte dye adsorption index,\% & $37.4 \pm 3.1$ & $28.0 \pm 2.1^{*}$ \\
\hline Bursa of Fabricius & & $27.3 \pm 2.4^{*}$ \\
B(C3)-immunocytes, \% & $44.0 \pm 1.2$ & \\
Bursocyte dye adsorption index, \% & $38.1 \pm 6.2$ & $26.0 \pm 1.0^{*}$ \\
\hline Spleen & $59.0 \pm 1.5$ & $12.0 \pm 1.6^{*}$ \\
T-immunocytes, \% & $23.0 \pm 3.5$ & $78.6 \pm 1.5$ \\
B(C3)-immunocytes, \% & $85.9 \pm 5.7$ & \\
Spleenocyte dye adsorption index, \% & & \\
\hline
\end{tabular}

${ }^{*}$ Statistically different from the control group $(\mathrm{P}<0.05)$

and solitory hepatocyte necrosis in liver. The tissue injury was increased parallel to the dose of $\mathrm{Cd}$. The damage mechanism of $\mathrm{Cd}$ in tissues is operated mainly by cellular oxidative stress. It is associated with overproduction of reactive oxygen species, highly unstable and extremely reactive biochemical products. The result of their reactivity is the damage of important biological molecules (cleavage of DNA, protein denaturation and breakdown lipid membranes) in a variety of biological systems (Oh \& Lim, 2006; Nair et al., 2013; Moitra, Brashier, \& Sahu, 2014). The level of lipid peroxidation induced by $\mathrm{Cd}$ in tissues of Cd-exposed chickens was studied by the accumulation of MDA in selected organs (Table 2). MDA is consider to be one of the cytotoxic end product of lipid peroxidation formed by the reaction of oxygen free radicals with cellular membrane lipids and proteins. The increase of MDA production in Cdtreated chickens indicates the high susceptibility of Cd target organs and central organs of immune system to lipid peroxidation, resulted in cell damage. So, MDA concentration in thymus and bursa was enhanced under $\mathrm{Cd}$ influence by $29.0(\mathrm{P}<0.05)$ and $57.1 \%$ $(\mathrm{P}<0.05)$, respectively.

This data accord with a decrease of immunocyte vital adsorption index in these organs (Table 3).
The accumulation of MDA, cytotoxic product of lipid peroxidation, in central organs of immune system followed by a cytotoxic effect, and resulted in immune dysfunction. The same effect of functioning suppression in lesser degree was marked in spleen also (see Table 2). Cd harmful action produced a functional depression in adaptive immunity; both in $\mathrm{T}$ - and B-derived immune system (see Table 3). It manifested by a reduction of immunocompetent cell number in organs of immunity of Cd-exposed chicks: by $52.3 \%$ in bursa in comparison with the control $(\mathrm{P}<0.05)$. An evidence of Cd inhibitory effect on functioning of organs of immunity also is a significant decrease of T- and B (C3)- immunocompetent cell populations in spleen $(\mathrm{P}<0.05)$. The reduction in immunocyte number in organs of immune system of Cd-treated chicks likely was caused by Cd-induced oxidative stress followed by cell breakdown, and cell proliferation disturbances. In addition, to immunocompetent cell depletion the low relative mass coefficient in these organs was found (Table 4). The general character of Cd suppressive action on the chicken health was reflected in pronounced avian growth retardation: body mass of Cd-exposed birds was 2.5 times lower in comparison with the control $(\mathrm{P}<0.001)$. These results are comparable with data from other studies. Using of

\section{Influence of cadmium exposure on body mass and relative mass of inner organs of chickens}

\begin{tabular}{|l|c|c|c|c|c|c|}
\hline \multirow{2}{*}{ Group } & \multirow{2}{*}{$\begin{array}{c}\text { Chicken body } \\
\text { mass, g }\end{array}$} & \multicolumn{5}{|c|}{ Relative mass of organ, g $100 \mathrm{~g}^{-1}$ body mass } \\
\cline { 3 - 7 } & & Liver & Kidney & Spleen & Thymus & $\begin{array}{c}\text { Bursa of } \\
\text { Fabricius }\end{array}$ \\
\hline Control & $1275.0 \pm 166.6$ & $1.98 \pm 0.15$ & $0.73 \pm 0.07$ & $0.11 \pm 0.01$ & $0.38 \pm 0.06$ & $0.22 \pm 0.01$ \\
\hline+ Cd & $500.0 \pm 169.9 * *$ & $2.84 \pm 0.16^{*}$ & $1.23 \pm 0.19 *$ & $0.10 \pm 0.05$ & $0.21 \pm 0.01^{*}$ & $0.11 \pm 0.02^{*}$ \\
\hline
\end{tabular}

${ }^{*}$ Statistically different from the control group $(\mathrm{P}<0.05)$.

${ }^{* *}$ Statistically different from the control group $(\mathrm{P}<0.001)$. 
the toxic Cd level (25 mg per kg) in broiler diet leads to high Cd accumulation in tissues, greatly decreases nutrient consumption and body mass of birds (Akyolcu et al., 2003). Oxidative stress induced by $\mathrm{Cd}$ in chickens via the drinking water ( $25 \mathrm{mg} \mathrm{Cd}$ per $\mathrm{L}$ ) for 6 weeks, plays a decisive role in a strong decrease in the performance of broiler (Erdogan et al., 2005).

\section{Conclusions}

The intensive increase of $\mathrm{Cd}$ concentration in organs of immunity in 35-day-old chickens exposed by Cd (8.25 mg per $\mathrm{kg}$ of diet) for 5 weeks was observed. The high level of $\mathrm{Cd}\left(\mu \mathrm{g} \mathrm{g}^{-1}\right.$ wet wt) was detected in bursa of Fabricius - $7.90 \pm 1.27$, thymus $-1.35 \pm 0.21$ and spleen $-5.15 \pm 0.92$. The significant susceptibility of immunocompetent organs to $\mathrm{Cd}$ accumulation followed by tissue oxidative stress induction and organ immune functional disturbances indicate the pronounced immunosuppressive effect of exogenous $\mathrm{Cd}$ in broiler chickens.

\section{References}

1. Akyolcu, M.C., Ozcelic, D., Dursun, S., Toplan, S., \& Kahraman, P. (2003). Accumulation of cadmium in tissue and its effect on live performance. J.Phys. 1 Y France. 107, 33-36.

2. AOAC. (1999). Determination of lead, cadmium, copper, iron and zinc in foods. Atomic Absorption Spectrophotometry after Dry Ashing. Official method 999.1.1

3. Berzina, N., Apsite, M., Smirnova, G., \& Basova, N. (2002). Cadmium disturbances antioxidant defense system in chicks. In 21. Workshop Macro and Trace Elements, 18-19 October 2002 (pp. 693-698). SCHUBERT-Verlag, Leipzig.

4. Berzina, N., Markovs, J., Isajevs, S., Apsite, M., \& Smirnova, G. (2007). Cadmium-induced enteropathy: biochemical and histological study. Basic \& Clinical \& Pharmacology \& Toxicology. 101(1), 29-34.

5. Bokori, J., \& Fekete, S. (1995). Complex study of the physiological role of cadmium. I. Cadmium and its physiological role. Acta Veter. Hungar. 43(1), 3-43.

6. Bokori, J., Fekete, S., Kadar, J., Koncz, J., Vetesi, F., \& Albert, M. (1995). Complex study of the physiological role of cadmium. III. Cadmium loading trials on broiler chickens. Acta Veter. Hungar. 43(2-3), 195-228.

7. Brzóska, M., \& Rogalska, J. (2013). Protective effect of zinc supplementation against cadmium-induced oxidative stress and the RANK/RANKL/OPG system imbalance in the bone tissue of rats. Toxicol. Appl. Pharmacol. 272, 208-220.

8. Brzóska, M., Borowska, S., \& Tomczyk, M. (2016). Antioxidants as a potential preventive and therapeutic strategy for cadmium. Curr. Drug Targets. 17, 1350-1384.

9. Davison, F. (2014). The importance of the avian immune system and its unique features. In Karel A.Schat, Bernd Kaspers, \& Pete Kaiser (Eds.), Avian Immunology (Second Edition) (pp. 1-9). Academic Press.

10. El-Boshy, M.E., Risha, E.F., Abdelhamid, F.M., Mubarak, M.S., \& Hadda, T.B. (2015). Protective effects of selenium against cadmium induced hematological disturbances, immunosuppressive, oxidative stress and hepatorenal damage in rats. J. Trace Elem. Med. Biol. 29, 104-110.

11. Erdogan, Z., Erdogan, S., Celik, S., \& Unlu, A. (2005). Effects of ascorbic acid on cadmium - induced oxidative stress and performance of broilers. Biol. Trace Elem. Res. 104(1), 19-32.

12. Ferraro, P.M., Costanzi, S., Naticchia Sturniolo, A., \& Gambaro, G. (2010). Low level exposure to cadmium increases the risk of chronic kidney disease: analyses of the NHANES 1999-2006. BMC Public Health. 10, 304.

13. Galazyn-Sidorczuk, M., Brzóska, M., Rogalska, J., Roszczenko, A., \& Jurczuk, M. (2012). Effect of zinc supplementation on glutathione peroxidase activity and selenium concentration in the serum, liver and kidney of rats chronically exposed to cadmium. J. Trace Elem. Med. Biol. 26, 46-52.

14. Järup, L., Berglund, M., Elinder, C.G., Nordberg, G., \& Vahter, M. (1998). Health effects of cadmium exposure - a review of the literature and a risk estimate. Scand. J. Work Environ. Health. 24(1), 1-52.

15. Järup, L., \& Åkesson, A. (2009). Current status of cadmium as environmental health problem. Toxicol. Appl. Pharmacol. 238, 201-208.

16. Kah, M., Levy, L., \& Brown, C. (2012). Potential for effects of land contamination on human health. 1. The case of cadmium. J. Toxicol. Environ. Health B Crit. Rev. 15, 348-363.

17. Moitra, S., Brashier, B., \& Sahu, S. (2014). Occupational cadmium exposure associated oxidative stress and erythrocyte fragility among jewellery workers in India. Am. J. Ind. Med. 57, 1064-1072.

18. Moulis, J-M., \& Thévenod, F. (2010). New perspectives in cadmium toxicity: an introduction. Biometals. 23(5), 763-768.

19. Nair, A.R., De Gheselle, O., Smeets, K., Van Kerkhove, E., \& Cuypers, A. (2013). Cadmium-induced pathologies: where is the oxidative balance lost (or not)? Int. J. Mol. Sci. 14, 6116-6143. 
20. National Research Council. (1994). Nutrient Requirements of Poultry 9 $^{\text {th }}$ Rev. Edc. (pp. 33-35). National Academy Press. Washington D.C.

21. Oh, S.H., \& Lim, S.Ch. (2006). A rapid and transient ROS generation by cadmium triggers apoptosis via caspase dependent pathway in HepG2 cells and this is inhibited through $\mathrm{N}$-acetylcysteine-mediated catalase upregulation. Toxicol. Appl. Pharmacol. 212, 212-223.

22. Ohkawa, H., Ohishi, N., \& Yagi, K. (1979). Assay for lipid peroxidation in animal tissues by thiobarbituric acid reaction. Analytical Biochemistry. 95(2), 351-358.

23. Olah, I., Nagy, N., \& Vervelde, L. (2014). Structure of the avian lymphoid system. In Karel A.Schat, Bernd Kaspers, \& Pete Kaiser (Eds.), Avian Immunology (Second Edition) (pp. 11-44). Academic Press.

24. Surai, P.F., Noble, R.C., \& Speake, B.K. (1996). Tissue-specific differences in antioxidant distribution and susceptibility to lipid peroxidation during development of the chick embryo. Biochim. Biophys. Acta. 1304, 1-10.

25. Wallin, M., Sallsten, G., Lundh, T., \& Barregard, L. (2014). Low-level cadmium exposure and effects on kidney function. Occup. Environ. Med. 71, 848-854.

26. Wang, P., Wang, G., Sun, Y.J., Yang, L., \& Wu, Y.J. (2017). Cadmium and chlorpyrifos inhibit cellular immune response in spleen of rats. Enviromental Toxicology. 32 (7), 1927-1936.

27. Zhang, Z., Zheng, Z., \& Cai, J. (2017). Effect of cadmium on oxidative stress and immune function of common carp (Cyprinus carpio L.) by transcriptome analysis. Aquatic Toxicology. 192, 171-177.

28. Васильева, С., Берзиня, Н., \& Ремез, И. (2001). Комплекс методов для оценки воздействия кадмия и цинка на иммунитет птицы. Методы оценки иммунитета у птиц (The complex of methods for the estimation of cadmium and zinc effect on chicken immunity. Methods of estimation of immunity in birds). Baltic J. Lab. Anim. Sci. 11, 149-159 (in Russian). 